\title{
Teaching International Studies in Nigerian Universities
}

\author{
ADESINA, Oluwakemi Abiodun \\ Department of History and International Studies, College of Humanities, Redeemer's University, Ede \\ Osun State, Nigeria.
}

\begin{abstract}
The teaching of 'International Studies' (IS) has become the 'rave' in Nigerian Universities. But to fully capture what is driving this, one needs to explore the existential anxieties and the cultural consciousness of the so-called 'Cheetah' generation and compare their assumptions with those of their teachers. Since the adoption of the Structural Adjustment Programme (SAP) in 1986 and the elevation of neo-liberal market economics, Nigerian youths have developed particular understandings of what it means for a vocation to be 'marketable'. This paper is based on a survey of graduates, students and lecturers of IS in order to investigate the perceived tension between what the Cheetah generation wants and what the university/lecturers think they should be teaching. It is also an analysis of the extent to which the IS element has either circumscribed the career prospects or globalized the graduates of these combined honours degree programmes.

This paper concludes that teaching history without IS is unattractive to the Cheetah generation, however, in reality, there is little or no difference in the course content but a mere highfalutin course name.
\end{abstract}

Keywords: International Studies, History, Cheetah Generation, Marketability, University, and Nigeria.

\section{INTRODUCTION}

The imagination that created 'International Studies' (IS) as an aspect of the Nigerian educational curriculum had sought to induce a more 'professionally-inclined' and globally competitive generation that would take its pride of place in the scheme of things. The IS that came into existence since the 1990s has however taken on a diverse character to the extent that it has proved notoriously difficult to define. This is because the notion has always taken on a peculiar character based on the Faculty or Department and even the institution in which it is domiciled. A critical aspect of this vast difference also includes under what circumstances it developed. In some Nigerian Universities, IS belongs to the Faculty of Social Sciences while in others it belongs in the Liberal arts. At the nine-year-old Osun State University (UNIOSUN) where I taught, IS is a proud member of the Liberal Arts family.At the inception of the university, a major objective of the young institution proclaimed the need: 'to provide academic, professional and vocational training of high quality in such a way as to enrich and improve the state, national, and international human resources capabilities and assist its graduates to contribute to the common good of society.'[1] The subject of IS, is, however, regarded as a child of circumstances. To many, the introduction and inclusion of IS in the programme of Nigerian universities represent 'reason' as it was expected to be of more contemporary relevance more than several other 'ancient' disciplines and courses being paraded by the institutions. My primary focus in the analysis of the contemporary trajectory of IS is in its relation to the discipline of history. In the Department of History and International Studies at the College of Humanities and Culture of the Osun State University, Nigeria, which was established in 2007, the IS became part and parcel of the old subject of History at inception. The reasons for this were obvious. For the field of history in older Nigerian institutions, student enrolment had from the 1990s nose-dived critically. The general apathy to History is evident in the low enrolment figures recorded across universities in Nigeria.[2] In addition, History was no longer 'marketable'. A graduate of History was doomed to become a 'mere' school teacher, and not even of history - since History was 'useless and irrelevant' - but of subjects like Government, Social Studies, Civics Education or English. In order to address this situation, some historians engaged in formulating survival strategies for the discipline through nomenclature change and hybridization; to enhance the marketability of the historical discipline.[3] This way, historians have continued to hold on to history while latching on to something else.

The other fields in the humanities did not fare any better. The new universities in Nigeria began to diverge from the old scholarship taking on board programmes that redefined the socialisation processes in the country. The curricula of the courses in the College of Humanities and Culture at the new Osun State University became hinged on national and international issues for the socio-political and economic development of the Nigerian society. The mantra became to develop the intellectual abilities of its students in preparation for future careers in diverse fields. 


\section{FROM STRUCTURAL ADJUSTMENT TO THE NEW FUTURE}

Towards the close of the twentieth century, courses in the humanities suffered from the fear of extinction. One of the major causes of this fear was the adoption of the Structural Adjustment Programme (SAP) in 1986 and the elevation of neo-liberal market economics. The implementation of SAP promoted the so-called professional course like Law, Business Administration, and the sciences and technology disciplines. The non-professional and the non-sciences and technology courses were classified as 'useless' and 'irrelevant' disciplines.[4] Science and technology, in particular, were conceived as means of attaining the much-needed development. Thus, governments of different African countries adopted National policies on education to promote the sciences to the detriment of the humanities. The National Policy on Education in Nigeria even proclaimed as follows:

(a) A greater portion of education expenditure will be adopted by science and technology,

(b) Universities and other levels of the education system will be required to pay greater attention to the development of scientific orientation.

(c) The enrolment ratio of 60:40 for science and the liberal arts respectively in the Universities will be maintained.[5]

One of the most badly hit in the humanities was the History discipline. The subject of History was no longer being taught in most schools and across levels (Primary, Secondary, and Tertiary schools) in Nigeria.

In reaction to this new 'market' orientation decreed by SAP, several departments in the humanities began to offer a creative blend of 'professional' degree courses in International Studies (IS) as combined honours. The old single honours course began to atrophy. The IS programme at the College of Humanities and Culture, Osun State University, Osogbo (Ikire Campus) took off with the following programmes: English and International Studies; French and International Studies; and History and International Studies. It is the assumption of the 'Cheetah' (fast, impatient, upwardly mobile and internet-savvy) generation and the University that the linking of IS to courses in the Humanities and Culture would make the students at graduation more 'marketable'. The 'Cheetah' generation, according to Ayittey, [6] is defined as 'the new and angry generation of young African graduates and professionals, who look at African issues and problems from a totally different and unique perspective." The question now is how did the universities respond to the desires of this generation, and how did the teachers cope with the demands of this generation?

\section{NIGERIAN UNIVERSITIES AND NOMENCLATURE CHANGE}

As Nigerian universities sought to make courses in the Humanities more marketable, they responded to the increasingly interdependent and inter-related nature of the global society. The introduction of International Studies to the English, French and History curricula were designed to expose the undergraduates enrolled in these programmes to aspects of world politics, economy, history, cultures, and societies of the world.[7] The following Nigerian Universities run combined honours degree programmes with an 'International Studies' component: Osun State University, Osogbo; University of Nigeria, Nsukka; University of Ilorin; Delta State University; University of Calabar; Bowen University, Iwo; Redeemers University, Mowe, Ogun State; University of Benin; Lagos State University; Ekiti State University; Nnamdi Azikiwe University, Awka, Anambra State.

At the heart of the objectives of the Department of History and International Studies' of the Osun State University is the aspiration of producing students with critical and analytic minds with the capacity to analyze national and international issues for the socio-political and economic development of the society. While English, French, and History are combined with International Studies at the Osun State University, History and International Studies is combined with one of the following, Archaeology, Education, English, Library Science and Information Technology and Religion; at the University of Nigeria, Nsukka, (UNN) [8]. The IS programmes across the country are in reality designed to prepare students for careers in education (teaching and research), public and private administration, external affairs; immigration, customs, police and prison services, embassies, information, public relations, personnel management and labour relations, archival and museum services, diplomatic service, non-governmental organisations, cultural affairs, library services, politics, advertising, banking, and related professions. In these Nigerian universities, the duration of degree programmes in all humanities courses are three years minimum for direct entry candidates and four years for candidates who applied to the universities through the writing of the Unified Tertiary Matriculation Examination (UTME). All universities operate a two-semester year calendar.

\section{THE IS PEDAGOGY}

The strategies espoused to realize the objectives of encouraging IS education are the teaching of courses about history, politics, world affairs, information technology and an International language; French. These courses are taught across the four-year duration of the programme and at the end, the successful graduates of the programme are awarded the Bachelor of Arts degree in English and International Studies, French and 
International Studies, and History and International Studies. At the Osun State University, the IS component of these programmes is domiciled in the Department of History and International Studies. In view of the colonial and postcolonial relationships between Europe and Africa, academics in the department designed courses that teach African experiences from pre-colonial times to the present, European experiences since the 1300s, critical issues in Nigerian history, world/global issues as they affect Africa, and of course; mainstream concerns of IS.

In spite of this, a noticeable tension between what the 'Cheetah generation' - the graduates; wanted, and what the university/lecturers have taught have become a noticeable aspect of student/teacher experiences. Teaching Africa and IS at the College of Humanities and Culture since 2007 has been very exploratory, intensive, engaging and interesting. The challenges we had been facing as teachers of History and International Studies are multifarious and multifaceted. They range from the number of courses taught, number of students in each class, most rewarding style of teaching, availability of teaching aids, internet facilities and above all power supply. It must be noted that the hybridization of courses encouraged a high rate of enrolment in the combined honours courses with International Studies. According to Adesina, [9] enrolment of students to the Department of History at the premier University of Ibadan in Nigeria ${ }^{1}$ dwindled drastically; in 1978 there were a hundred and forty students, by 1986 the population of students reduced to seventy-six, and by 1999 students' enrolment had reduced drastically to nineteen. While in UNIOSUN, the combination of courses in the humanities with IS has continued to experience a progression in the enrolment of students.

TABLE 1

Enrolment Of Students In International Studies Between 2012/13 And 2013/14 Academic Session In Uniosun ${ }^{2}$

\begin{tabular}{|l|l|l|l|l|}
\hline S/No & Year & $\begin{array}{l}\text { ENGLISH } \\
\& \text { IS }\end{array}$ & $\begin{array}{l}\text { FRENCH } \\
\& \text { IS }\end{array}$ & $\begin{array}{l}\text { HISTORY } \\
\& \text { IS }\end{array}$ \\
\hline 1. & $2012 / 13$ & 118 & 25 & 99 \\
\hline 2. & $2013 / 14$ & 219 & 30 & 86 \\
\hline
\end{tabular}

IS has been taught through historical lenses. International Studies has been taught with the intent of teaching history as the foundation of all global relations. I am one of the graduates of pure history who had to teach IS. However, the observation of teachers of IS is that a majority of students who applied for the combined honours degree have little or no knowledge of the subject of history; because the teaching of history is almost extinct in secondary schools in Nigeria. The lack of knowledge in history has been highly problematic because at most times students have not been interested in the course contents of the courses mounted in history. When we observed the facial expressions of these students they ranged from disinterest, hopelessness, and displeasure; their attention span in class waned within thirty minutes. This development was quite worrisome that we had to devise a means of sustaining students' interest. Thus, classes were participatory as students were organized into groups of presenters and discussants. This style of teaching encouraged the 'Cheetah generation' to read widely and soon we overcame the problems posed by their lack of knowledge in history. Though classes became more interesting and feedback from students was garnered from class discussions and tests, we have continued the process of fine-tuning the pedagogy for the course.

I have taught several courses in the past seven years. These courses are: European History, 1300-1789; European History, 1789-1945; European History, 1945-1991; Ancient Civilization up to the Fall of the Roman Empire; Major Civilization Since the Fall of Rome; Warfare and Diplomacy in Africa up to 1900; History of International Relations Since 1945; The Third World in International Relations; The Third World and the World Economy; and The Problems of Nation Building in Africa. In consonance with the philosophy and objectives of the Department of History and International Studies, courses taught in the department "offers students the opportunity to study the past, not only for its own sake but for the perspectives it offers the present." [10] Teaching IS was a daunting task at first. As a graduate of history with B.A., M.A., and Ph.D. History degrees, I was taught stories and the act of writing the stories, but I had to teach the stories, its essence, implication and application of the stories for development purposes. Therefore, as a teacher of IS in UNIOSUN, I have made attempts to ensure that the analytical tools deployed to the understanding of history are also deployed to make students understand bonds tying people of African descents worldwide. The experiences have also placed respectful attention to human relations, thereby allowing them to undergo an alteration of consciousness from being a Nigerian to becoming a global citizen.

The process of differentiation between History and IS comes alive in class every day. While some students exhibited interest some displayed apathy. Theirs is a generation that thrives on visuals. Thus, the lecture

\footnotetext{
${ }^{1}$ While other universities engaged in the hybridization of courses, the Department of History at the premier University of Ibadan in Nigeria retained its nomenclature.

${ }^{2}$ I was furnished with these figures by the Registry Unit of the Osun State University, Osogbo (UNIOSUN).

DOI: 10.9790/0837-2109071221 $\quad$ www.iosrjournals.org $\quad 14 \mid$ Page
}


style was designed to incorporate visual teaching aids like the electronic boards, reliable internet facility, slides and projectors to present lectures in simplified and illustrative forms. But due to the erratic power supply in Nigeria, the integration of these teaching aids in the lecture rooms have been impossible. Indeed, this equipment would have broadened the horizons of the students and made teaching easier. A considerable length of time is, therefore, spent describing different parts of the world to these students; who through their own exposure to web resources at personal levels equally expect their classroom experiences not only to be extremely stimulating but highly rewarding. While the highly urbanized segment of the students has continued to display considerable élan, those from the rural side appeared a bit lost. As a result of this, arguments and counter arguments have often played out from this social divide. This is evident in the questions raised in classes. For example, in a global development class, students wanted to know why Nigeria cannot be referred to as a developed economy in view of the fact that Nigerians ride luxury cars, live in luxury houses, and possess private jets - though a myopic definition of development, it is their understanding of development. The analogy of the indices of development becomes insufficient and ephemeral in the absence of experiential evidence and observations; which could have been derived through visits to one or two developed countries of the world, internships at International organizations' offices within and outside the country and through the physical observations of the workings of International Agencies. While multimedia equipment has become a veritable teaching tool for this generation of students; it is not entirely sufficient.

In recent times, the integration of films and podcast reviews in teaching modules has been used for introducing international relations with the view of investigating, synthesizing, and analysing the continent's international studies in relation to other continents, because the Cable News Network (CNN) effect has over time created an ambivalent understanding of development indicators among this generation of Nigerian students. However, this is only attainable in private owned (fee paying) universities in Nigeria like the Redeemer's University, where the erratic power cuts in the country is augmented with the use of standby generators. The constant references to the Cable News information and other online videos (Youtube etc.) has inevitably overridden several arguments proffered by their teachers. In order words, the consciousness of the new generation is now more attuned to Cable News information than classroom analysis without any visual pieces of evidence. It is worth noting that Osun State University is also a fee paying institution but managed by the government. It is in the nature of private owned organisations to deliver service for its money's worth.

Another major concern of the teachers of IS is the conflict that arises over long essay project topics. At most times students are interested in writing topics such as U.S. -Nigerian Relations, Comparative Democratic Systems of the United States of America and Nigeria, Comparative Analysis of the Foreign Policies of Major Powers and Nigeria etc. However, in the face of inadequate resources, paucity of funds and ultimately, methodological issues, many of the IS topics have been turned down in favour of mostly mainstream historical and local topics like "The History of Palm Oil Trade in Ikire"; "The Osun-Osogbo Groove", but, in order to accommodate the IS content we have approved such topics like; "The Role of UNICEF in Polio Eradication in Osun State, 1991-2011". To the students, this was a great contradiction between their expectation and what their teachers felt they should investigate.

\section{POST-GRADUATION CAREER PROSPECTS}

An assessment of the responses of the teachers of IS and the three sets of graduates since the 2010/2011 academic session through questionnaires reveal most fundamentally that all but one of the ten teachers of these combined honours courses was a graduate of IS. International Studies in Osun State University has been subsumed within the subject of History. Again, of all the ten teachers in the department, only one is not a graduate of history. He graduated with a B.Sc. in Political Science. At the postgraduate level, the teachers are graduates of a complementary blend of History, Peace and Conflict Studies, International Relations, and Diplomatic Studies. All of these have been applied to the teaching of IS.

The relevance of courses taught to post-graduation pursuits and experiences of the students of IS, and the extent to which the IS element has either circumscribed the career prospects or globalized the graduates of these combined honours are of great significance for this study. To carry out these investigations, I designed two questionnaires (See appendixes I and II); one for the graduates of IS and the other for their teachers.

University education in Nigeria has over time responded to the exigencies of its milieu; from the transition from colonial rule to independence to post-independence global realities. The universities have gone through the stages identified by Mackenzie [11] as the "nationalization of universities", "the decolonization of universities", and what I refer to as the "globalization of universities." This globalization of universities commenced from the attempts at creating what James Coleman called "Developmental Universities." [12] These were African universities responses to the multifarious schema of African political leaders and the demands of the American and International community that university education should "be all things to all men" [13]. Several African leaders expressed in detail their visions of African universities as invoked by ideas of African pioneers like Africanus Horton, Edward Blyden and Casely Hayford. 


\section{POPULATION OF RESPONDENTS}

Since the focus of this research is on graduates of the IS programme and their teachers, I obtained the e-mail addresses of the graduates from the Alumni unit of the Osun State University, Osogbo, and forwarded the questionnaire to them. Of the one hundred and fifty-six emails sent, fifty-nine graduates responded and seventeen emails bounced back. All ten lecturers in the department responded to the questionnaires. Altogether, sixty-six respondents completed the survey. By age, most of the graduates belong to the 26-30 age brackets while most of the lecturers belong to the 46-70 age bracket. All questionnaires were administered between May 2014 and June 2015

\section{GRADUATES OF HISTORY AND INTERNATIONAL STUDIES AND THEIR LECTURERS}

By interfacing responses of the graduates - the 'cheetah generation' - with that of their lecturers; I intend to evaluate the effectiveness of the teaching of IS and investigate the tension between what the Cheetah generation wants and what the university/lecturers think they should be teaching and the extent to which the IS element has either circumscribed the career prospects or globalized the graduates of these combined honours. In a similar survey by Adebayo [14], it was stated that most history students applied for the course as a fall-back plan, after they failed to secure admission to read law and other courses in the social sciences. He further observed that most of these students later grew to like History once they took a few classes while many still remained apathetic.In my own survey, same questionnaires were distributed to two categories of graduates of IS from the Osun State University; those who have remained in Nigeria and those who have sought graduate studies in the developed countries. The same questionnaires were also given to all the lecturers of IS.

Since I hold the view that students applied to read IS believing it enhanced their 'marketability', I asked if they thought the 'International Studies' component of their courses improved their marketability? An overwhelming majority responded in the affirmative; here are some of their responses (these respondents are graduates who have remained in Nigeria):

Respondent 14: Yes, it has because International Studies is a very fluid discipline that slithers through almost every career path. Thus, it created so many options to choose from aside the usual academic path that those single honours courses like history offers.

Respondent 46: Yes. Aside the fact that it has widened the scope of our thinking, it has also helped us to apply for jobs in international organizations and we have mostly been chosen because of our critical thinking which our training has given us.

Respondent 50: Yes it has. In actual fact, lots of organisations; most especially those which deal with the formulation of policies or those who are research oriented, prefer that one is trained in such areas in order to help add value to their system.

Respondent 53: One who has studied International Studies has an edge over those who did not because he/she is seen as one who at all times think out of the box and could, therefore, be part of a small group of people who have the capacity to engineer diverse ideas for the development of a particular organisation.

Following the acceptance of the marketability of their course of study, I asked if they were you satisfied with their course of study. One reason that best captures the opinions of other respondents is cited below:

Respondent 02: Certainly! It is one course that broadens your horizon, makes you think critically, and gives you an understanding of why the present is what it is and what the past was. I am also satisfied because I am wellequipped with the knowledge and understanding of certain issues around the world and why they happen. I am satisfied for the simple fact that I am well-trained to find and apply my course of study in places where solutions to problems are hard to come by.

It will not be right to assume that these graduates enjoyed their experiences in all of the four years they spent studying at UNIOSUN. Though I conceded that they were satisfied with their courses of study I asked that they listed five to ten things they did not like or find appealing about their courses of study. My interrogation revealed that:

Respondent 01: One is usually loaded with studying so many courses that are not related to each other which yet must be dealt with. For example French literature and History of West Africa. This makes studying very stressful. And also, your lecturers expect too much from you regardless of whether their course is your area of interest or specialty. You could become a jack of all trade and master of none; who only read to pass. To make matters worse, there are inadequate pedagogical materials.

Respondent 28: Both courses were confusing at the end of the day. I understood some part of International Studies and only the literary part of English.

The response of the latter respondent resonates with the concern of a lecturer. Commenting on postgraduate prospects of these graduates, the teacher observed that graduates of English and International Studies and 
French and International Studies are disadvantaged because they some major components of English, French, and International Studies are omitted from their curriculum to ensure the workload is bearable.

Generally, the lecturers are not too happy with their teaching techniques. Here is a list of their challenges in teaching IS courses:

- Lack of teaching aids

- A Large population of students to teach. This makes interaction difficult and assessment a problem.

- Paucity of current literature and teaching aids

This survey recognizes the implicit strengths and weaknesses in the teaching of IS in my university. For graduates of my institution who are presently undergoing postgraduate studies in the developed world; there is a gulf in the learning experience.

Here is my dialogue with one of them on Facebook:

Question 1

Were you satisfied with your choice of study at UNIOSUN?

Response:

Yes, I am satisfied with my choice of study as it helped lay a strong foundation for my graduate studies. In addition, it helped me develop an interest in international events/affairs.

Question 2

Do you think the "International Studies' component of your course has improved your marketability? Give reasons

Response:

Yes, I think it has improved it. One reason is that I already had a background in International Studies and could also expand international relations arguments and discussions from a historical view. Moreover, I have core knowledge of some African events which also has a tremendous impact on the happenings in international affairs, and also have courses from European and Asian Studies. Combining all these has therefore improved my marketability as my knowledge is not just restricted to a particular part of the continent.

\section{Question 3}

What were your experiences at the beginning of your postgraduate studies?

Response:

At the beginning, it was a stage of acclimatizing due to the obvious difference in the academic system. I also had to understand the different ways/methods employed by the different lecturers like no written exams and the submission of term papers etc. Some placed more work on individual presentation, but they all generally encouraged discussion. I also noticed that relevant materials that would help students were readily available on the department's portal.

Question 4

From your recent experiences in the West, discuss things you did not find appealing in the teaching of IS at UNIOSUN.

\section{Response:}

First, I won't say I found the method of teaching at UNIOSUN unappealing as the institution laid a good footing for most of us, but I would say there is definitely room for improvement as there is a huge difference in the system back home from the system operated here, at least from my experience and below are some of my reasons: The use of 'Wikipedia' or another encyclopaedia is not popularly accepted as a source/reference since anyone can easily upload information and articles to these websites. Students are therefore advised to use sources like Google Scholar, Mendeley among others. I also didn't know much about plagiarism and the academic consequence that comes along with it. During my undergraduate days, I could easily 'copy-paste' any material and get away with it. We are however made to realize that it is a 'sin' in International Studies and in academics as a whole. In addition, the use of video and audio recordings, first-hand interviews, as well as commentary by respectable media houses and persons are emphasized on here, as it gives first-hand knowledge in teaching and studying International Studies. There are the availability and free access to the use of journals and articles to study important events in the international sphere, as there is less emphasis on the use of textbooks which are also readily available in the library. In most of the courses related to International Studies that I have done, we sometimes have about two lecturers taking a course and the idea is to have different opinions and views from the teachings and thereafter balance our ideas. Also, there are seminars regularly conducted related to International Studies and we have had the chance to have heads or representatives of international organizations like the UN Secretary-General, members of the European Parliament amongst others 
as guest speakers. We have also had academic trips to the headquarters of the European Union in Brussels and the European Parliament in Strasbourg and the motive is to get direct knowledge of what we must have been taught in the class. - Furthermore, for some courses that I have offered, some of the lecturers don't go for written exams but rather have oral exams where we interact and discuss lessons learnt in class and our contribution as well as feedback on these lessons. To them, competence is not solely demonstrated by examination. Finally, although we have a small number of students; fifteen (15) in my class, we are usually divided into groups of three or four depending on the lecturer and are assigned topics to deliberate on individually and collectively as a group. I had this experience at UNIOSUN as well, but the difference is that these smaller groups ensure the contribution of everyone. It is, however, important to acknowledge limitations like unstable electricity and travel difficulties that could make some of the above mentioned realizable in UNIOSUN and in some other educational institutions in Nigeria.

\section{Question 5}

In retrospect, how do you think the teaching of IS can be improved?

Response:

From my own perspective, I think the introduction or use of more electronic devices that have video or audio recording of events will help increase the interest of students in International Studies. It will also lessen the over reliance on textbooks and notes given to students by the lecturers and possibly turn the class into a more interactive one where the lecturers and students discuss.

\section{CONCLUSION}

This work was prompted by my observation of a sudden increase in the number of student's enrolment in the Humanities in new generation universities in Nigeria due to a nomenclature change with the addition of International Studies (IS) to courses in the humanities, for example, English and International Studies. History and International Studies etc. This paper relied heavily on responses of students, graduates, and teachers of these new programmes to questionnaires that I administered. This work argues that the initial rejection of History as a single honours course and the acceptance of the IS combined honours course is more of a nomenclature change than a fundamental change in curriculum. As stated by Asiwaju, “... the phenomenon of wide spreading change of name of Departments of History in some of our nation's tertiary institutions has been acclaimed as an original contribution." To this end, Asiwaju [15] posed the following questions:

Is the question of relevance effectively addressed by a change of disciplinary identity?

And,

Isn't there a confusion in equating the whole to a part in such new names as 'Department of History and International Studies' in LASU and 'Department of History and Strategic Studies' in ... UNILAG ... when we know that the discipline, is by definition, all-inclusive.

This article has looked into the outcomes of the hybridization of some courses in the humanities programme of the Osun State University. The analysis revolved around the premise that the addition of International Studies to courses in the humanities in some Nigerian varsities generally and specifically in the Osun State University was geared towards making the humanities courses more attractive to applicants and boosting the marketability of graduates of such courses; in view of the diminishing global relevance of the humanities.

On this premise, the article's motivation was to contribute, through dialogue with the teachers of IS and their graduates; to understand the range of socio-economic relations and forces that has influenced the course content of the International Studies component of the combined honours programmes at the College of Humanities and Culture, Osun State University and the realities for the graduates.

An assessment of the responses of the teachers of IS and the three sets of graduates since the 2010/2011 academic session through questionnaires reveal most fundamentally that all but one of the ten teachers of these combined honours courses was a graduate of IS. International Studies in Osun State University has been subsumed within the subject of History. Again, all but one of the ten teachers is not a graduate of history but of Political Science. At the postgraduate level, the teachers are graduates of a complementary blend of History, Peace and Conflict Studies, International Relations, and Diplomatic Studies. These multidisciplinarities have been applied to the teaching of IS.

However, the survey reveals that initially, most of the graduates had no preference for their course of study. As observed by Adebayo, [16] these students had applied to read Law, Mass Communication, and Political Science. They were unable to secure admissions in their preferred courses and combined honours programmes in English and International Studies, French and International Studies, and History and International Studies became fall-back plans. The attraction in settling for these courses was the combination with International Studies. These graduates believed the International Studies component of their courses prepared them for work in the Foreign Service Department of the Nigerian Civil Service, Embassies and High 
Commissions, and other International Agencies. All of them want to be diplomats. They wanted to be marketable; not restricted to teaching jobs.

The interface between the 'cheetah generation' and their teachers most importantly revealed the gaps in the curriculum, an assessment of how the courses were taught, self-critique by lecturers, and areas where the teaching and curriculum of IS can be improved. Indeed, the survey has provided a deeper understanding and knowledge that will promote a better teaching of IS in Africa to the 'cheetah generation'. It is worth pointing out that the combined honours (English and International Studies, French and International Studies, and History and International Studies) exist in subordinate and superordinate relationship. Respondents to these questionnaires have imposed the need to engage in a critical analysis; the features of History and International Studies in the course content and curriculum of these combined honours degrees, so that we can begin to properly establish IS not as a subordinate but a partner with English, French, and History. However, while students still clamoured for these combinations, by the end of this research in June 2015, lecturers of English and French expressed their dissatisfaction for the combination with IS because according to them, it prevented their students from gaining mastery of their major courses and circumscribed their prospects for higher degrees. To this end, these programmes are reverting to single-honours courses. Though this might be true for some isolated cases, I observed from questionnaires that graduates of these courses have actually broadened their options. While some sought admission in single disciplines, for example, M.A. English, M.A. French, some others were admitted for M.Sc International Relations, M.Sc Peace and Conflict Studies etc. In few years, this study suggests a reassessment of the introduction of the single-honours to examine the number of applications for these programmes.

\section{REFERENCES}

[1] Osun State University, College of Humanities and Culture, Ikire Campus,2007/2008 Handbook, 2011 (Osogbo, Nigeria: Osun State University, 2007). See also Departmental Handbook of the Department of History and International Studies, College of Humanities and Culture, Osun State University, 2010/2011 (Osogbo, Nigeria: Osun State University, 2010) pp. 1-61.

[2] Olukoju, A. "Rethinking Historical Scholarship in Africa" in S. Akinrinade et.al. (eds.) Rethinking the Humanities in Africa, (Ile-Ife, Nigeria: Faculty of Arts, Obafemi Awolowo University, 2007) pp. 167182.

[3] Adesina O.C. "Teaching History in Twentieth Century Nigeria: The Challenges of change", History in Africa: A Journal of Method, 33, 2006 pp. 17-37.

[4] Olukoju, A. "Rethinking Historical Scholarship in Africa" in S. Akinrinade et.al. (eds.) Rethinking the Humanities in Africa, (Ile-Ife, Nigeria: Faculty of Arts, Obafemi Awolowo University, 2007) pp. 167182.

[5] National Policy on Education (1998) as cited by Balogun, O.A. (2006) "Humanities, Man and Technology in Africa: A Philosophical Appraisal" in S. Akinrinade et.al. (eds.) The Humanities, Nationalism and Democracy, (Ile-Ife, Nigeria: Faculty of Arts, Obafemi Awolowo University, 2006) pp. 405-419.

[6] Ayittey, G. "Why Africa needs 'cheetahs,' not 'hippos" CNN [online] 2010, Available from http://edition.cnn.com/2010/OPINION/08/25/ayittey.cheetahs.hippos/ [Accessed 23 May 2014].

[7] Marks, M.P. "The "We" Problem in Teaching International Studies", International Studies Perspectives 3, 2002 pp. 25-41.

[8] The University of Nigeria, Nsukka, (UNN) http://unn.edu.ng/department/history-and-internationalstudies [Accessed on 13 June 2016].

[9] Adesina O.C. "Teaching History in Twentieth Century Nigeria: The Challenges of change", History in Africa: A Journal of Method, 33, 2006 pp. 17-37.

[10] Osun State University, Osogbo (UNIOSUN) http://www.uniosun.edu.ng/index.php/department-ofhistory-and-international-studies.html [Accessed on 15 June 2016].

[11] MACKenzie, C.G. "Prisoners of Fortune: Commonwealth African Universities and their Political Masters", Comparative Education Volume 22, No. 2, 1986 pp. 111-121.

[12] Ade-Ajayi, J.F.A. "The American Factor in the development of Higher Education in Africa" in James Smoot Coleman Memorial Papers Series, (Los Angeles: African Studies Center, University of California, 1988) pp. $1-23$.

[13] Ade-Ajayi, J.F.A. "The American Factor in the development of Higher Education in Africa" in James Smoot Coleman Memorial Papers Series, (Los Angeles: African Studies Center, University of California,1988) pp. $1-23$.

[14] Adebayo, A.G. "HISTORY AND HISTORIANS: Who is Afraid of Us?" Paper presented at the Nigerian Network of Historians Roundtable, University of Ibadan, Ibadan, on December 15, 2010 pp. 1 -19. 
[15] Asiwaju, A.I. "Whither, Nigerian Historian?" in Language and Good Governance and the Necessity of History. Ed.Ogude, Steve Occassional Publications of The Nigerian Academy of Letters, No.5. (Benin City, Nigeria: Uniben Press, 2007) pp.67-103.

[16] Adebayo, A.G. "HISTORY AND HISTORIANS: Who is Afraid of Us?" Paper presented at the Nigerian Network of Historians Roundtable, University of Ibadan, Ibadan, on December 15, 2010 pp. 1 -19.

\section{APPENDIX I \\ A QUESTIONNAIRE \\ HUMANITIES STUDENTS' VIEW OF INTERNATIONAL STUDIES}

Dear Respondent:

You are invited to participate in my research on Nigerian students' view of the discipline of International Studies by completing the attached questionnaire. The questions are open-ended and require you to write in your answers. Your responses are voluntary and will be confidential. Responses cannot be traced back to you. All responses will be compiled together and analyzed as a group. The survey will take about fifteen minutes of your time. Participation in this survey will not cause you any harm. Also, your participation does not carry any monetary reward but you will be contributing to knowledge. If you have questions or concerns, please don't hesitate to contact me.

Sincerely

Oluwakemi A. Adesina, Ph.D.

Department of History and International Studies

[1] Name of your Institution

[2] Please mark $\mathrm{X}$ in the appropriate section

[3] $2 . \quad$ Male; _

[4] What is your age bracket (choose one)?

[5] (19-25); (26-30);

[6] Are you __ Working or ___ a Postgraduate student/graduate?

[7] If Postgraduate, how many years have you spent in this University?

[8] What level? __ (e.g., 700 level if postgraduate, or thesis writing stage of the postgraduate).

[9] 7. During your undergraduate programme, was History/English/ French and International Studies your First Choice; Second Choice?

[10] In a few sentences, state your aspiration or career goals:

[11] Briefly, state why you chose History/English/French and International Studies as your course of study?

[12] Would you have accepted to come for a single honours course (if Yes, which one)?

[13] In the space below, list five to ten things you like about History/ English/French and International Studies as a discipline/course of study.

[14] List two to five of your favourite courses during the undergraduate programme (course title, not course number or lecturer).

[15] List five to ten things you do not like or did not find appealing about History/English/French and International Studies as a discipline/course of study.

[16] Describe in a few words your opinion on how graduates of single honours courses like History, English, and French are considered in your country.

[17] Are you aware of resources or opportunities available for graduates of single honoured courses like History, English, and French in your country? ___ Yes; ___ No. If yes, list a few of them.

[18] Do you think as a graduate of International Studies, you have a better career prospect than graduates of single-honours courses? ___ Yes; ___ No. If yes, list a few of them.

[19] In the space below, list any fears or concerns you have about the discipline of History/English/French and International Studies in your country.

[20] Do you think the "International Studies" component of your course has improved your marketability? Give reasons

[21] Are/Were you satisfied with your course of study? Give reasons

[22] As a postgraduate student or worker, what challenges did you face after graduation?

[23] From your NYSC experience(s), what would you say is/are the connection(s) between what you learnt in school and your primary assignments? 
[24] After your NYSC programme, what options are/were available to you- most especially in the light of the training you received at the university?24 If you applied for graduate studies, what choices have you made?

[25] Thanks for sparing time to fill this questionnaire.

\section{APPENDIX II \\ A QUESTIONNAIRE \\ HUMANITIES LECTURERS’ VIEW OF INTERNATIONAL STUDIES \\ Dear Respondent:}

You are invited to participate in my research on Nigerian lecturers' view of the discipline of International Studies by completing the attached questionnaire. The questions are open-ended and require you to write in your answers. Your responses are voluntary and will be confidential. Responses cannot be traced back to you. All responses will be compiled together and analyzed as a group. The survey will take about fifteen minutes of your time. Participation in this survey will not cause you any harm. Also, your participation does not carry any monetary reward but you will be contributing to knowledge. If you have questions or concerns, please don't hesitate to contact me.

Sincerely

Oluwakemi A. Adesina, Ph.D.

Department of History and International Studies 08033565532

[1] Name of your Institution

[2] 2. Male;

Female

[3] What is your age bracket (choose one)?

[4] (26-30); __ (31-45); _ _ (46-70)

[5] Do you teach ____ Undergraduate or ____ Postgraduate? Or____ both?

[6] How many years have you spent in this University?

[7] Present Position? (e.g., Assistant Lecturer, Lecturer II, Professor etc.

[8] What is your academic qualification? Was it History/English/ French? or a combined honours with International Studies ?

[9] In a few sentences, state your career goals:

[10] Briefly state If your career goals and aspirations have changed since you were employed in this University?

[11] What, in your opinion, should be contained in an International Studies Curriculum?

[12] What are your hopes/ aspirations/ career prospects for your students?

[13] What are the challenges of teaching International Studies Courses?

[14] List two to five of your favorite courses so far (course title that you have taught and state if they are compulsory or electives)

[15] From your observation, how have your students responded to these courses?

[16] How have you coped with teaching International Studies?

[17] Describe in a few words your opinion on how graduates of single honour courses like History, English, and French are considered in your country.

[18] If you are from a pure Humanities background, what would you say are the advantages and disadvantages of these combinations History/English/French and International Studies as a discipline/course of study?

[19] What options, in your opinion, are available to graduates of IS combined honours courses?

[20] Are you aware of resources or opportunities available for graduates of single honour courses like History, English, and French in your country? Yes; No. If yes, list a few of them.

[21] Do you think graduates of International Studies, have better career prospects than graduates of singlehonour courses? ___ Yes; ___ No. If yes, list a few of them.

[22] In the space below, list any fears or concerns you have about the discipline of History/English/French and International Studies in your country.

[23] As Lecturers who have graduated students over the years, what challenges have your students faced after graduation?

[24] Thanks for sparing time to fill this questionnaire. 